\title{
The Psycho-Behavioural Treatment/Management of Prematureejaculation among Adults
}

\author{
Ali Haruna \\ Department of Sociology, Yobe State University, P. M. B. 1144 Gujba Road, Damaturu. Yobe State. Nigeria.
}

\begin{abstract}
Premature ejaculation, a psychosexual condition affecting more than $75 \%$ of young men globally and causing undue suffering to young men is reviewed in this paper. The condition though just being identified in Nigeria has been discussed by earlier scholars in the USA and UK. Psychological presentation and management of two cases are discussed in this article. The first case was assessed using stress and anxiety psychology tools, Enugu Somatization scale (Ebigbo, 1982) and STAI 1 \& 11, Speiberger, (1974). The results indicated high levels of anxiety and stress. These conditions were identified as causes of the disorder. The behavioural treatment was successful at four weeks follow up. The second case also of a similar diagnosis was arrived at using Awaritefe psychological index (Awaritefe, 1985) and STAI 1 \& 11 (Spelberger, 1974) revealed no presence of any psychotic problem but high levels of anxiety respectively. Behavioural Treatment was also successful at longer follow up period of 12 months. The results are discussed alongside the etiological factor of underlying anxiety in both cases. Further Implications for Clinical Psychology practice are discussed.
\end{abstract}

Keywords: Behavioural Treatment, Premature Ejaculation, Adults

\section{Introduction}

Premature ejaculation is a sexual dysfunction experienced by men irrespective of one's age bracket. Diagnostic and statistical manual of mental disorders (DSM IV-TR) of American psychiatric association (APA, 2000) defines premature ejaculation as the persistent or recurrent onset of orgasm and ejaculation with minimal sexual stimulation before, on or shortly after penetration and before the person wishes it.

Globally this disorder has been reported among men in the USA (masters and Johnson, 1970 and Lopicolo, 1978). In Africa the disorder is not reportedly seen in the clinics. Awaritefe (1986) reported the treatment of functional impotence among Nigerian men. Likewise Dada, (1986) reported treating impotence among the Yoruba of Nigeria.

\section{Prevalence}

Premature ejaculation is a prevalent sexual dysfunction in men; Laumann, E.O., et al. (1999). However, because of the variability in time required to ejaculate and in partners' desired duration of sex, exact prevalence rates of premature ejaculation are difficult to determine. In the "Sex in America" surveys (1999 and 2008), University of Chicago researchers found that between adolescence and age 59, approximately $30 \%$ of men reported having experienced premature ejaculation at least once during the previous 12 months, whereas about 10 percent reported erectile dysfunction (ED).E.O., et al. (1999). Although erectile dysfunction is men's most prevalent sex problem after age 60, and may be more prevalent than premature ejaculation overall according to some estimates, Schouten BW, Bohnen AM, Groeneveld FP, Dohle GR, Thomas S, Bosch J.L. (2010). Premature ejaculation remains a significant issue that, according to the survey, affects 28 percent of men age 65-74, and 22 percent of men age 75-85.E.O., et al. (1999). Other studies report premature ejaculation prevalence ranging from 3 percent to 41 percent of men over 18, but the great majority estimate a prevalence of 20 to 30 percent-making premature ejaculation a very common sex problem.Barnes T., I. Eardley (2007), Mayo Clinic, (2007),Mathers, M.J. et al. (2013),Serefoglu E.C. and T.R. Saitz (2012),Tang, W.S. \& E.M. Khoo (2011),Althof, S.E. et al. (2010),Porst, H. et al. (2007),Rowland, D. et al. (2004).

There is a common misconception that younger men are more likely to suffer premature ejaculation and that its frequency decreases with age. Prevalence studies have indicated, however, that rates of premature ejaculation are constant across age groups. Althof, S. E. (2007).

\section{Causes}

The causes of premature ejaculation are unclear. Many theories have been suggested, including that premature ejaculation was the result of masturbating quickly during adolescence to avoid being caught by an adult, of performance anxiety, of an unresolved oedipal conflict, of passive-aggressiveness, and having too little sex-but there is little evidence to support any of these theories. Strassberg, D. S., \& Perelman, M. A. (2009). 
Several physiological mechanisms have been hypothesized to contribute to causing premature ejaculation including serotonin receptors, a genetic predisposition, elevated penile sensitivity, and nerve conduction atypicalities. Althof, S. E. (2007).

The nucleus paragigantocellularis of the brain has been identified as involved in ejaculatory control. Kaplan, Helen S. (1989), Scientists have long suspected a genetic link to certain forms of premature ejaculation. In one study, 91 percent of men who have had premature ejaculation for their entire lives also had a first-relative with lifelong premature ejaculation. Other researchers have noted that men who have premature ejaculation have a faster neurological response in the pelvic muscles.

Premature ejaculation may be caused by prostatitis, Althof, S.E. et al. (2010). Or as a drug side effect.

\section{Sex Therapy}

Several techniques have been developed and applied by sex therapists, including Kegel exercises (to strengthen the muscles of the pelvic floor) and Masters and Johnson's "stop-start technique" (to desensitize the man's responses) and "squeeze technique" (to reduce excessive arousal).LeVay, S., \& Baldwin, J. (2009).

To treat premature ejaculation, Masters and Johnson developed the "squeeze technique". Men were instructed to pay close attention to their arousal pattern and learn to recognize how they felt shortly before their "point of no return", the moment ejaculation felt imminent and inevitable. Sensing it, they were to signal their partner, who squeezed the head of the penis between thumb and index finger, suppressing the ejaculatory reflex and allowing the man to last longer. Castleman, M. (2004), Masters, W. and V. Johnson (1970), Belliveau, F. and L. Richter (1970).

The squeeze technique worked, but many couples found it cumbersome. From the 1970s to the 1990s, sex therapists refined the Masters and Johnson approach, largely abandoning the squeeze technique and focused on a simpler and more effective technique called the "stop-start" technique. During intercourse, as the man senses he is approaching climax, both partners stop moving and remain still until the man's feelings of ejaculatory inevitability subside, at which point, they are free to resume active intercourse. Castleman, M. (2004),Kaplan, Helen S. (1989),Metz, M. and B. McCarthy (2003),Silverberg, S. (1978, 2010),Birch. R.W. (2007). To help the man increase awareness of his sexual experience, he is encouraged to create an excitement scale of 1-100. Successful completion of this scale will include paying attention to his heart rate, when (and if) he squeezes his inner thighs, and sensations in all parts of his body. By creating this scale, he will be more able to pace himself as he uses the "stop-start" technique.

In addition to the stop-start technique, other sexual adjustments help men develop and maintain ejaculatory control, among them: masturbation exercises, deep breathing, and whole-body massage. Sex therapists estimate that the refined last-longer program teaches effective ejaculatory control to 90 percent of men. Castleman, M. (2004), Kaplan, Helen S. (1989), Metz, M. and B. McCarthy (2003), Silverberg, S. (1978, 2010), Birch. R.W. (2007). The authors of one study concluded that sex therapy "has a remarkable therapeutic effect on premature ejaculation." Chen, G.H. et al. (2009).

Premature ejaculation has been found to be associated with coital anxiety (Razani 1978, Wolpe, 1973, Awaritefe, 1986, Dada, 1986). Razani, 1978, cited Coper, 1969 as having found a correlation index of $94 \%$ coital anxiety and male potency disorders in a study of 49 patients he undertook. Further report shows that in the past this disorder was infrequent, (Masters and Johnson, 1970). This paper presents the treatment of premature ejaculation using behaviour therapy techniques.

\section{Case 1.}

Mr. Zoo is a 32 years old secondary school teacher of impressive body weight and of average height. Mr. Zoo was referred for management by a chief medical consultants of the Jos University Teaching Hospital (JUTH) to Psychology unit of the same Hospital. In-depth interview revealed that the young man had a good upbringing and was socially tied to his parents. The Father a staunch Christian, always preached and punished behaviours that had to do with sex, and substances of abuse including alcohol. The Father never allowed visits to their house by opposite sex friends, or allowed them visit such friends. This young man believed affected his social intercourse with the opposite sex and the first sexual intercourse he had, was loaded with anxiety, nervousness, fear and guilt. His relationship with the opposite sex has always been accompanied with nervousness and tense feelings. His marital history showed a marked and tensed sexual bonding with his spouse. Any time the couple advanced for sexual intercourse he would ejaculate before full vaginal intromission. Following which his eraction would die out and he would sleep off. At this point the partner would shout out to neighbours for help believing that her husband had fainted and may pass on. Eventually the neighbour's noise would wake him up. Anxiuos and confused he would blame and castigate himself for incompetence.

This development always angered his spouse and out of frustration she would and complaint about their marriage because of incompetence sexual life, which cause more anxiety to the young man. State-trait anxiety inventory $1 \& 11$ (STAI 1\&11) administered on him showed very high levels of stress. 
His work history revealed a hard working personality who was liked and respected by the school administrators, fellow colleagues and students. In order to maintain this achievement records he set for himself, he would leave his house in the morning at 5:00 am to attend the morning devotion with the students and would stay at school engaged in one routine or the other until 11:00 pm after his last routine of the day (students' bed check and lights out).

A diagnosis of premature ejaculation was made following the summary of the presentation.

\section{Treatment/ Management}

His condition was induced by anxiety and stress, hence three behavioural management techniques were put in place for intervention, these includes;

- Discussion of his daily work schedules

- $\quad$ Training in deep muscle relaxation (DMR)

- $\quad$ Squeeze technique training

The management lasted for eight sessions. The first session discussed history of the client to map out areas of difficulties. The second session further discussed the client's work history and the subsequent stress accumulated from it and reorganizing his life style. While the third, fourth and fifth sessions were spent on training, practicing and mastery of deep muscle relaxation. In the last session the client received training and practice squeeze technique exercise with the spouse without engaging in intra-virginal sex. The couples reported satisfaction with their sex life at four weeks follow up.

Case 2.

A forty year old stout and of average height and a successful businessman was referred by a medical consultant from university teaching hospital Jos (JUTH) to the Clinical psychology unit for management. He came in search of treatment for his inability to delay ejaculation for the sexual satisfaction of his wife. He has had this problem for more than six years, the length of his marriage. State-Trait anxiety inventory $1 \$ 11$ administered showed high level of anxiety. His sexual relationship was also attended with high levels of anxiety in wanting to satisfy his demanding wife. Awaritefe Psychological Index (API) Awaritefe, (1985) administered did not reveal any accompanying psychopathology. If not for his problem otherwise his marital life is very stable as he described it. A diagnosis of premature ejaculation was made having ruled out any possible medical and biological antecedents.

\section{Treatment/Management}

Since the wife did not accompany him to the country to partake in squeeze technique training another technique was employed to manage his situation. Deconditioning his sexual anxiety plan was focused on through pairing in vivo training of built up hierarchy of sexual anxiety steps with deep muscle relaxation (DMR) over ten sessions of 50 minutes each. However, the management only lasted for eight sessions.

- $\quad$ Night fall (dusk)

- Discussing with his wife in the lounge

- Facing each other in the room

- Hugging each other fully dressed

- $\quad$ Sitting on the edge of the bed

- Lying in bed in each other's arm fully dressed

- In bed naked cuddling each other

- Wife holding and stroking him

- Intro-virginal strokes

At 12 months follow up the client was still practicing delayed ejaculation for a normal sexual intercourse with his spouse.

\section{Discussion}

In both cases the client's had no difficulty in achieving primary eraction, the difficulty centered on their inability to delay ejaculation for the spouse to be sexually satisfied. This confirms the claim by Masters and Johnson (1970) cited in Razani, (1979), that a man with ejaculation incompetence rarely has difficulty in achieving of maintaining the eraction necessary for successful coitus. The problem usually arises during the first coital experiences and continues if unresolved by subsequent attempts. Pressure to succeed will further worsen the condition. Similarly anxiety as the bases of ejaculation incompetence was reported by Awaritefe (Awaritefe, 1986) among Nigerian client's he managed. However,several physiological mechanisms have been hypothesized to contribute to causing premature ejaculation including serotonin receptors, a genetic predisposition, elevated penile sensitivity, and nerve conduction atypicalities. Althof, S. E. (2007). In both cases presented here recovery followed specific deconditioning of anxiety evoked by the coital stimulation. 
Similarly, other studies report premature ejaculation prevalence ranging from 3 percent to 41 percent of men over 18, but the great majority estimate a prevalence of 20 to 30 percent-making premature ejaculation a very common sex problem. Barnes T., I. Eardley (2007), Mayo Clinic, (2007),Mathers, M.J. et al. (2013),Serefoglu E.C. and T.R. Saitz (2012),Tang, W.S. \& E.M. Khoo (2011),Althof, S.E. et al. (2010),Porst, H. et al. (2007), Rowland, D. et al. (2004).

The result of these management techniques implication in clinical psychology practice call for an eclectic use of technique in managing premature ejaculation, a condition now seen among young people in our society. Client's social history is important for the clinician to understand the source of the anxiety, which would now be managed by other behavioural methods.

\section{References}

[1] Althof, S. E. (2007). Treatment of rapid ejaculation: Psychotherapy, pharmacotherapy, and combined therapy (pp. 212-240). In S. R. Leiblum (Ed.), Principles and practice of sex therapy (4th Ed.). NY: Guilford.

[2] Althof, S.E. et al. (2010). "International Society for Sexual Medicine's Guidelines for the Diagnosis and Treatment of Premature Ejaculation". Journal of Sexual Medicine7 (9): 2947.

[3] American Psychiatric Association (2000). Diagnostic and statistical manual of mental Disorders, Fourth edition. Text revesion. Washington DC.

[4] Awaritefe A. (1986). The Treatment of functional impotence. Nigerian Journal of Clinical Psychology, 5, 1 \& 2, 57-61.

[5] Barnes T., I. Eardley (2007). "Premature Ejaculation: The Scope of the Problem". Journal of Sex and Marital Therapy33 (3): 151.

[6] Belliveau, F. and L. Richter (1970), Understanding Human Sexual Inadequacy, Hodder and Stoughton

[7] Birch. R.W. (2007), A Short Book about Lasting Longer, PEC Publishing, pp. 27-38

[8] Birch. R.W. (2007), A Short Book about Lasting Longer, PEC Publishing, pp. 16-44

[9] Castleman, M. (2004), Great Sex, Rodale Inc., pp. 136-137

[10] Castleman, M. (2004), Great Sex, Rodale Inc., pp. 137-138

[11] Castleman, M. (2004), Great Sex, Rodale, Inc., pp. 122-141

[12] Chen, G.H. et al. (2009). "A Clinical Study on Psycho-Behavioral Therapy for Premature Ejaculation". Zonghua Nan Ke Xua (Chinese journal)15 (10): 929.

[13] Ebigbo, P. (1982). "A cross sectional study of somatic complaint of Nigerian females using the Enugu Somatization Scale." Culture, Medicine and Psychiatry, 10, 167-186.

[14] End premature ejaculation (2009). Essential review.com

[15] http//www.intelhealth.com (2010). Behavioural management of premature ejaculation, Medical count reviewed by Harvard medical school.

[16] Kaplan, Helen S. (1989), PE: How to Overcome Premature Ejaculation, Brunner Mazel/New York Times, p. 28

[17] Kaplan, Helen S. (1989), PE: How to Overcome Premature Ejaculation, Brunner Mazel/New York Times, pp. 43-61

[18] Kaplan, Helen S. (1989), PE: How to Overcome Premature Ejaculation, Brunner Mazel/New York Times, pp. 48-58

[19] Laumann, E.O., et al. (1999). "Sexual Dysfunction in the United States: Prevalence and Predictors". Journal of the American Medical Association281: 537.

[20] LeVay, S., \& Baldwin, J. (2009). Human sexuality (3rd. Ed.) (pp. 532-534). Sunderland, MA: Sinauer.

[21] Masters, W. and V. Johnson (1970), Human Sexual Inadequacy, Little Brown \& Company.

[22] Mathers, M.J. et al. (2013). "Premature Ejaculation in Urological Routine Practice". Aktuelle Urology (German)44 (1): 33

[23] Metz, M. and B. McCarthy (2003), Coping With Premature Ejaculation, New Harbinger Publications, pp. 105-133

[24] Metz, M. and B. McCarthy (2003), Coping With Premature Ejaculation, New Harbinger Publications, pp. 123-128"Premature ejaculation". Mayo Clinic.com. Retrieved 2007-03-02

[25] "Premature ejaculation". Mayo Clinic.com. Retrieved 2007-03-02

[26] Porst, H. et al. (2007). "The Premature Ejaculation Prevalence and Attitudes (PEPA) Survey: Prevalence, Co-morbidities, and Professional Help-Seeking". European Urology51 (3): 816.

[27] Razani, (1978). Ejaculatory Incompetence treated by decondition anxiety. In Lopicolo, J \& Lopicolo, 1. (Eds). Hand book of sex therapy. London. Plenum Press.

[28] Rowland, D. et al. (2004). "Self-Reported Premature Ejaculation and Aspects of Sexual Functioning and Satisfaction". Journal of Sexual Medicine1 (2): 225.

[29] Schouten BW, Bohnen AM, Groeneveld FP, Dohle GR, Thomas S, Bosch JL (July 2010). "Erectile dysfunction in the community: trends over time in incidence, prevalence, GP consultation and medication use - the Krimpen study: trends in ED". J Sex Med7 (7): 2547-53.

[30] Serefoglu E.C. and T.R. Saitz (2012). "New Insights on Premature Ejaculation: A Review of Definition, Classification Prevalence, and Treatment". Asian Journal of Andrology14 (6): 822.

[31] Silverberg, S. (1978, 2010), Lasting Longer: The Treatment Program for Premature Ejaculation, Physicians Medical Press, Pp. 4257

[32] Silverberg, S. (1978, 2010), Lasting Longer: The Treatment Program for Premature Ejaculation, Physicians Medical Press, Pp. 44 57

[33] Strassberg, D. S., \& Perelman, M. A. (2009). Sexual dysfunctions. In P. H. Blaney \& T. Millon (Eds.), Oxford textbook of psychopathology (2nd ed.), (pp. 399-430). NY: Oxford University Press.

[34] Tang, W.S. and E.M. Khoo (2011). "Prevalence and Correlates of Premature Ejaculation in a Primary Care Setting: A Preliminary Cross-Sectional Study". Journal of Sexual Medicine8 (7): 2071.

[35] Wolpe, J. (1973). The Practice of behavioural therapy. New York. Pergolas. 